\title{
PENGELOLAAN DANA DESA DALAM PERSPEKTIF HUKUM ISLAM
}

\author{
NURHAYATI, MUH. SALEH RIDWAN \\ Fakultas Syariah dan Hukum Universitas Islam Negeri Alauddin Makassar
}

\begin{abstract}
Abstrak
Bentuk pengelolaan dana desa di desa benteng paremba dilakukan dengan beberapa tahapan yaitu pertama, perencanaan dimana yang dimulai dari musyawarah dusun kemudian musyawarah desa rencana kerja pemerintah Desa untuk menampung usulan masyarakat desa sebagai dasar untuk melakukan kegiatan dana desa dan kemudian dilanjutkan dengan pembuatan rencana anggaran biaya setiap kegiatan yang lalu dituagkan dalam anggaran pendapatan dan belanja desa sebagai dasar untuk menggunakan anggaran dana desa. Kedua tahapan pelaksanaan dibutuhkan keterbukaan dari tim pelaksana desa kepada seluruh masyarakat. Keterbukaan informasi ini merupakan usaha pemerintah desa untuk melaksanakan prinsip transparansi dalam pengelolaan dana desa. Pandangan hukum islam terhadap pengelolaan alokasi dana desa di desa benteng paremba yaitu dimana dalam islam kita diajarkan untuk selalu menanamkan sifat keterbukaan dan kejujuran dalam menjalan suatu perencanaan dalam hidup baik dalam bentuk individu maupun bermasyarakat.
\end{abstract}

Kata Kunci : Dana Desa, Hukum Islam, Pengelolaan.

\begin{abstract}
The form of village fund management in Benteng Paremba village is carried out in several stages, firstly, planning which starts from the hamlet consultation and then village consultation. The village government work plan is to accommodate the proposals of the village community as the basis for carrying out village fund activities and then proceed with the making of a budget plan for each cost. past activities are highlighted in the village income and expenditure budget as a basis for using the village budget. Both stages of implementation require openness from the village implementation team to the whole community. This information disclosure is an attempt by the village government to implement the principle of transparency in managing village funds. The view of Islamic law towards managing village fund allocation in Benteng Paremba village, where in Islam we are taught to always instill openness and honesty in running a plan in life both in the form of individuals and society.
\end{abstract}

Keywords: Islamic Law, Management, Village Funds. 


\section{A. PENDAHULUAN}

Desa adalah sebuah kesatuan masyarakat hukum yang memiliki batas batas wilayah yang berwenang untuk mengatur dan mengurus kepentingan masyarakat setempat, berdasarkan asal-usul dan adat istiadadt setempat yang diakui dan dihormati dalam sistem Pemerintahan Negara Kesatuan Republik Indonesia. ${ }^{1}$

Sebagai konsekuensi logis adanya kewenangan dan peran penting dari desa adalah tersedianya dana yang cukup. Salah satu sumber pendapatan desa yang ditetapkan dalam undang-undang nomor 32 tahun 2004 tentang pemerintahan desa adalah bagian dari dana perimbangan keuangan pusat dan daerah yang diterima oleh kabupaten/kota yang merupakan Alokasi Dana Desa (ADD).

Di dalam Islam dikemukakan prinsip-prinsip tentang pemerintahan, sebagaimana perintah Allah mengenai ulil amri (penguasa), seperti difirmankan dalam surah AnNisa/4: 59 yang berbunyi:

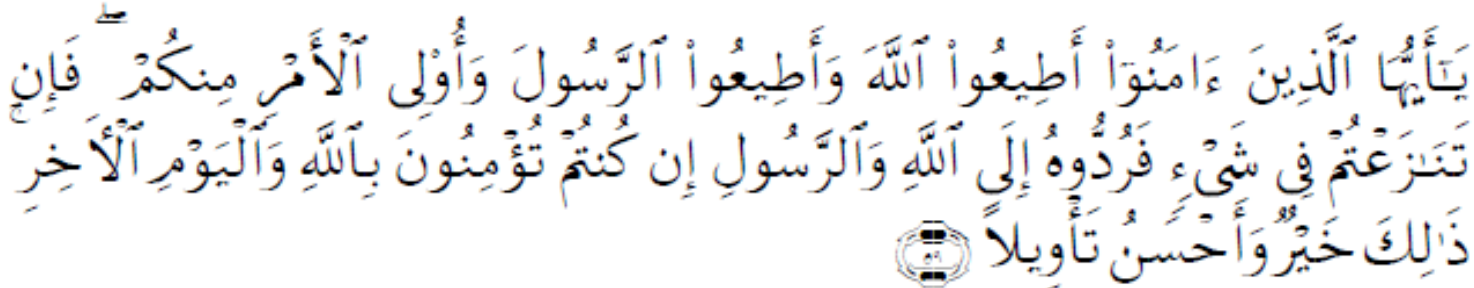

Terjemahnya:

"Wahai orang-orang yang beriman! Taatilah Allah dan taatilah Rasul (Muhammad), dan ulil amri (pemegang kekuaasaan) di antara kamu. Kemudian, jika kamu berbeda pendapat tentang sesuatu, maka kembalikanlah kepada Allah (Al-Quran) dan Rasul (Sunnahnya), jika kamu beriman kepada Allah dan hari kemudian. Yang demikian itu lebih utama (bagimu) dan lebuh baik akibatnya."

Ayat di atas memerintahkan kaum mukminin agar menaati putusan hukum dari siapa pun yang berwewenang menetapkan hukum. Secara berurutan dinyatakan Nya; Wahai orang-orang yang beriman, taatilah Allah dalam perintah-perintah-Nya yang tercantum dalam al-Qur'an dan taatilah Rasul-Nya, yakni Muhammad saw. dalam segala macam perintahnya, baik perintah melakukan sesuatu, maupun perintah untuk tidak melakukannya, sebagaimana tercantum dalam sunnah pnya yang sahih, dan perkenankan juga perintah ulil amri, yakni yang berwewenang menangani urusan-urusan kamu, selama mereka merupakan bagian di antara kamu wahai orang- orang mukmin, dan selama perintahnya tidak bertentangan dengan perintah Allah atau perintah Rasul-Nya. Maka jika kamu tarik-menarik, yakni berbeda pendapat tentang sesuatu karena kamu tidak menemukan secara tegas petunjuk Allah dalam al- Qur'an, dan tidak juga petunjuk Rasul dalam sunnah yang shahih, maka kembalikanlah ia kepada nilai-nilai dan jiwa tuntunan Rasul saw. yang kamu temukan dalam sunnahnya, jika kamu benar-benar beriman secara mantap dan besinambung kepada Allah dan hari Kemudian. Yang demikian itu, yakni sumber hukum ini adalah baik lagi sempurna, sedang selainnya buruk-atau memiliki kekurangan, dan di samping itu, ia juga lebih baik akhiratnya, baik untuk kehidupan dunia kamu maupun kehidupan akhirat kelak.

Adapun bila perintah taat diulangi seperti ayat di atas, maka di situ Rasulullah SAW memiliki wewenang serta hak untuk ditaati walaupun tidak ada dasarnya dari Al-Qur'an.

\footnotetext{
${ }^{1}$ Tim Visi Yustisia, Pedoman Resmi Petunjuk Pelaksanaan Dana Desa, (Jakarta: Visimedia, 2016),
} h. 15.

${ }^{2}$ Kementrian Agama Republik Indonesia, Syamil Al-Quran, (Bandung: Sygma, 2012), h. 87. 
Itu sebabnya perintah taat kepada ulil amri tidak disertai dengan kata taatilah karena mereka tidak memiliki hak untuk ditaati bila ketaatan kepada mereka bertentangan dengan ketaatan kepada Allah SWT atau Rasulullah SAW.

Pendapat ulama berbeda-beda tentang makna kata uli al-amr. Dari segi bahasa, uli adalah bentuk jamak dari waliy yang berarti pemilik atau yang mengurus dan menguasai. Bentuk jamak dari kata tersebut menunjukkan bahwa mereka itu banyak, sedang kata alamr adalah perintah dan urusan. Dengan demikian, uli al-amr adalah orang-orang yang berwewenang mengurus urusan kaum muslimin. Mereka adalah orang-orang yang diandalkan dalam menangani persoalan-persoalan kemasyarakatan.

Dalam ayat ini ditetapkan kewajiban atas masyarakat untuk taat kepada ulil amri, walaupun - sekali lagi - harus digarisbawahi penegasan Rasul saw. bahwa: la tha'ata li makhluqin fi ma'shiyati al-khaliq/tidak dibenarkan taat kepada seorang makhluk dalam kemaksiatan kepada Khaliq. Tetapi, bila ketaatan kepada ulil amri tidak mengandung atau mengakibatkan kedurhakaan, maka mereka wajib ditaati, walaupun perintah tersebut tidak berkenan di hati yang diperintah.

Taat dalam bahasa Al-Qur'an berarti tunduk, menerima secara tulus dan atau menemani. Ini berarti ketaatan dimaksud bukan sekadar melaksanakan apa yang diperintahkan, tetapi juga ikut berpartisipasi dalam upaya yang dilakukan oleh penguasa untuk mendukung usaha-usaha pengabdian kepada masyarakat. Dalam konteks inilah Nabi Muhammad saw. bersabda: ad-dinu an-nashihah/agama adalah nasihat. Ketika para sahabat bertanya: "Untuk siapa?" Nabi saw. antara lain menjawab, "Untuk para pemimpin kaum muslimin, dan khalayak ramai mereka" (HR. Muslim melalui Abu Ruqayyah Tamim Ibn Aus ad-Dari). Nasihat dimaksud adalah dukungan positif termasuk kontrol sosial demi suksesnya tugas-tugas yang mereka emban. ${ }^{3}$

Ayat ini juga mengisyaratkan berbagai lembaga yang hendaknya diwujudkan umat Islam untuk menangani urusan mereka, yaitu lembaga eksekutif, yudikatif, dan legislatif.

Dalam suatu riwayat dikemukakan bahwa turunnya ayat ini berkenaan dengan Abdullah bin Hudzafah bin Qais ketika diutus oleh Nabi saw. memimpin suatu pasukan. Diriwayatkan oleh al-Bukhari dan lainnya yang bersumber dari Ibnu Abbas dengan riwayat ringkas.

Menurut Imam ad-Dawudi riwayat tersebut menyalah gunakan nama Ibnu Abbas, karena cerita mengenai Abdullah bin Hudzafah itu adalah sebagai berikut: "disaat Abdullah marah-marah pada pasukannya ia menyalakan unggun api, dan memerintahkan pasukannya untuk terjun ke dalamnya. Pada waktu itu sebagian menolak dan sebagian lagi hampir menerjunkan diri ke dalam api". Sekiranya ayat ini turun sebelum peristiwa Abdullah mengapa ayat ini dikhususkan untuk mentaati Abdullah bin Hudzafah saja, sedang pada waktu lainnya tidak. Dan sekiranya ayat ini sesudahnya, maka berdasarkan hadis yang telah mereka ketahui, yang wajib ditaati itu ialah di dalam ma'ruf (kebaikan) dan tidak pantas dikatakan kepada mereka mengapa ia tidak taat.

Al-Hafidz Ibnu Hajar berpendapat bahwa maksud kisah Abdullah bin Hudzafah, munasabah disangkut pautkan dengan alasan turunnya ayat ini, karena dalam kisah itu dituliskan adanya perbatasan antara taat pada perintah (pimpinan) dan menolak perintah, untuk terjun ke dalam api. Di saat itu mereka perlu akan petunjuk apa yang harus mereka lakukan. Ayat ini turun memberikan petunjuk kepada mereka apabila berbantahan hendaknya kembali kepada Allah dan Rasul-Nya.

${ }^{3}$ M. Quraish Shihab, Tafsir Al-Mishbah Pesan, Kesan dan Keserasian Al-Qur'an, (Jakarta: Lentera Hati, Volume 3, 2002) h. 482-486.

Iqtishaduna: Jurnal Ilmiah Mahasiswa Jurusan Hukum Ekonomi Syariah 
Menurut Ibnu Jarir bahwa ayat ini turun berkenaan dengan 'Ammar bin Yasir yang melindungi seorang tawanan tanpa perintah Panglimanya (Khalid bin Walid) sehingga mereka berselisih. ${ }^{4}$

Keberadaan desa secara yuridis formal diakui dalam undang-undang nomor 32 tahun 2004 tentang pemerintahan daerah dan peraturan pemerintah nomor 72 tahun 2005 tentang desa.

Pemahaman desa di atas menempatkan desa sebagai suatu organisasi pemerintahan yang secara politis memiliki kewenangan tertentu untuk mengurus dan mengatur warga atau komunitasnya. Dengan posisi tersebut desa memiliki peran yang sangat penting dalam menunjang kesuksesan pemerintahan Nasiaonal secara luas.

Desa menjadi garda terdepan dalam menggapai keberhasilan dari segala urusan dan program pemerintah. Hal ini juga sejalan apabila dikaitkan dengan komposisi penduduk Indonesia atau sebagian besar penduduk indonesia saat ini masih bertempat tinggal di kawasan pemukiman pedesaan. Maka menjadi sangat logis apabila pembangunan desa menjadi prioritas utama bagi kesuksesan pembangunan nasional.

Agar dapat melaksanakan perannya dalam mengatur dan mengurus komunitasnya, desa berdasarkan ketentuan peraturan pemerintah nomor 72 tahun 2005, diberikan kewenangan yang mencakup:

1. Urusan pemerintahan yang sudah ada berdasarkan hak asal-usul desa.

2. Urusan pemerintahan yang menjadi kewenangan kabupaten/kota yang diserahkan pengaturannya kepada desa:

3. Tugas pembantuan dan pemerintah, pemerintah provinsi, dan pemerintah kabupaten/kota.

4. Urusan pemerintahan lainnya yang oleh peraturan perundang-undangan diserahkan kepada desa ${ }^{5}$

Sebagai konsekuensi logis adanya kewenagan dan tuntutan dan pelaksanaan otonomi desa adalah tersedianya dana yang cukup. Sadu Wasistiono menyatakan bahwa pembiayaan atau keuangan merupakan faktor esensial dalam mendukung penyelenggaraan otonomi desa, sebagaimana juga pada penyelenggaraan otonomi daerah. Sejalan dengan pendapat yang mengatakan bahwa "autonomy" identik dengan "auto money", maka untuk mengatur dan mengurus rumah tangganya sendiri, desa membutuhkan dana atau biaya yang memadai sebagai dukungan pelaksanaan kewenangan yang dimilikinya.

\section{B. METODE PENELITIAN}

Penelitian ini dilakukan dengan menggunakan jenis penelitian deskriptif kualitatif. Pendekatan penelitian yang dilakukan adalah yuridis normatif. Sumber data yaitu data primer dan data sekunder. Teknik pengumpulan data melakukan metode observasi, wawancara, dan dokumentasi. Data yang terkumpul dianalisis menggunakan analisis konvensional.

\section{PEMBAHASAN}

\section{Bentuk Pengelolaan Dana Desa di Desa Benteng Paremba}

${ }^{4}$ Qamaruddin Saleh Dahlan, Azbabun Nuzul Latar Belakang Turunnya Ayat-ayat Al-Qur'an, (Bandung: CV. Diponegoro, 1997), h. 139.

5 Saenong, Tinjauan Terhadap Pelaksanaan Kebijakan Alokasi Dana Desa, Skripsi, (Pinrang: Sekolah Tinggi Ilmu Hukum Cokroaminoto Pinrang, 2016), h. 2. 
a. Perencanaan Alokasi Dana Desa

Alokasi Dana Desa (ADD) adalah salah satu pendapatan desa yang penggunaannya terintegrasi dengan Anggaran Pendapatan dan Belanja Desa (APBDes), oleh karena itu program perecanaan dan kegiatannya disusun melalui musyawarah perencanaan desa (Musrenbangdes). Musrenbangdes adalah forum musyawarah yang membahas usulanusulan perencanaan atau program pembangunan desa yang berpedoman pada prinsipprinsip Perencanaan Pembangunan Masyarakat Desa (P3MD). Prinsip tersebut mengharuskan keterlibatan masyarakat dalam pengambilan keputusan dan menentukan pembangunan yang akan dilaksanakan khususnya yang beralokasi di desa yang bersangkutan, sehingga benar-benar dapat merespon kebutuhan/aspirasi yang berkembang.

Prinsip partisipasi adalah keterlibatan setiap warga Negara dalam pengambilan keptususan baik secara langsung maupun melalui institusi yang mewakili kepentingannya. ${ }^{6}$

Implementasi program ADD di desa benteng paremba kecamatan lembang kabupaten pinrang juga dilaksanakan dalam rangka pemberdayaan masyarakat dan menekankan proses motivasi berpartisipasi dalam pembangunan desa. Pelaksanaan partisipasi tersebut telah dibuktikan dengan hasil wawancara:

"Tingkat partisipasi masyarakat sangat baik. Terbukti saat adanya musrenbangdes masyarakat sangat antusias hadir dalam memberikan masukan program. Dan saat pelaksanaan masyarakat ada yang bersenang hati untuk membantu proses pembangunan dengan menjadi tukang atau kuli"?

Musyawarah desa membuka kesempatan untuk masyarakat dalam memberikan aspirasinya sekaligus sebagai media belajar bagi masyarakat terhadap prinsip akuntabilitas pengelolaan Alokasi Dana Desa. Unsur yang diundang dalam musyawarah desa ini meliputi Kepala Desa, Badan Permusyawaratan Desa (BPD), Kepala Dusun, Perangkat Desa, Unsur LPMD dan Unsur Kelembagaan Desa. Apabila ditinjau dari partisipasi dalam hal pengambilan keputusan perencanaan penggunaan dana Alokasi Dana Desa dapat dikatakan bahwa partisipasi masyarakat cukup baik.

Mengenai proses perencanaan alokasi dana desa sebagaimana di desa Benteng Paremba, proses penentuan skala prioritas pembangunan diawali dengan melakukan musyawarah dusun untuk menampung aspirasi masyarakat pada setiap dusun di desa benteng paremba. Setelah melakukan musyawarah dusun dan menetapkan usulan yang termasuk prioritas masing-masing masing dusun, maka dilanjutkan dengan musyawarah desa RKPDesa.

Musyawarah Desa RKPDesa dilakukan untuk merangkum semua usulan masyarakat desa, sebagai dasar untuk melakukan kegiatan dana desa tersebut. Pada proses musyawarah desa RKPDessa itu, melibatkan semua elemen masyarakat mulai dari pemerintah kecamatan, pemerintah desa, BPD, LKD, tokoh agama, tokoh pemuda, tokoh masyarakat, tokoh wanita, bidan desa, babin kamtibnas, babinsa dan pendamping desa. Setelah musyawarah desa RKPDesa selesai, kemudian dilanjutkan dengan pembuatan RAB setiap kegiatan yang lalu dituagkan dalam APBDesa sebagai dasar untuk menggunakan anggaran dana desa.

${ }^{6}$ A. Subroto, Akuntabilitas Pengelolaan Alokasi Dana Desa, thesis, (Semarang: Universitas Diponegoro, 2008), h. 36

${ }^{7}$ Muh. Yusuf, Kepala Desa Benteng Paremba, Wawancara, Pinrang 23 Desember 2017. 
Dalam hal pengelolaan dana desa yang sudah tertuang dalam APBDesa yang telah disetujui oleh BPD, maka untuk pelaksanaan kegiatan dibentuklah Tim Pelaksana Kegiatan (TPK) yang diberi tanggung jawab dalam kegiatan dana desa.

Perencanaan kegiatan yang bersumber dari Alokasi Dana Desa harus benar- benar mampu menampung aspirasi masyarakat. Semua kegiatan yang didanai Alokasi Dana Desa adalah program yang menjadi kebutuhan masyarakat dan menjadi prioritas untuk dilaksanakan guna tercapainya efektifitas penggunaan dana yang telah ditentukan oleh Pemerintah Kabupaten.

Hasil dari perencanaan anggaran dan program yang telah disahkan dengan Peraturan Desa ini akan menjadi pedoman penyelenggaraan pemerintah desa dan pembangunan desa dalam kurun waktu 1 (satu) tahun, disamping kegiatan lain yang sumber dananya di luar Alokasi Dana Desa. Dengan demikian perencanaan yang disepakati juga harus transparan, dapat diketahui oleh seluruh lapisan masyarakat yang nantinya dapat dipertanggungjawabkan.

Prinsip transparansi dijunjung tinggi oleh pelaksana program Alokasi Dana Desa di desa Benteng Paremba sehingga diharapkan memperoleh timbal balik/tanggapan dari masyarakat di dalam memperbaiki kinerja pembangunan. Disamping itu pemberian informasi diberikan secara terbuka mulai dari tahap perencanaan sampai pada kegiatan pembangunan. Hal tersebut dibuktikan dari hasil wawancara dengan informan yang mengatakan:

"Segala sesuatu yang menyangkut program ya disampaikan secara transparan mulai dari perencaannya, pengelolaannya dan akan diberi APBDes. Ini disampaikan karena kita menginginkan hal-hal yang tidak diinginkan. Menjadi keharusan untuk selalu terbuka."

Hal ini senada dengan yang disampaikan oleh seorang informan sebagai berikut:

"Adanya keterbukaan dan sesuai apa yang sudah menjadi RAP dan juga dilaksanakan oleh petugas yang memang ditugaskan. Dalam hal ini petugasan dalam melakukan kegiatan yaitu Timlak sesuai dengan anggaran dan pelaksanaan yang ada." 9

Informasi tersebut menunjukkan adanya penerapan prinsip transparansi di dalam perencanaan Alokasi Dana Desa yang dapat diketahui oleh seluruh masyarakat desa.

b. Pelaksanaan Alokasi Dana Desa

Pelaksanaan kegiatan-kegiatan yang pembiayaannya bersumber dari Alokasi dana desa sepenuhnya dilaksanakan oleh tim pelaksanaan kegiatan Desa. Dalam pelaksanaan Alokasi Dana Desa ini, dibutuhkan keterbukaan dari tim pelaksana desa kepada seluruh masyarakat. salah satu wujud nyata dari tim pelaksana desa di desa benteng paremba dalam mendukung keterbukaan informasi program Alokasi Dana Desa adalah dengan memasang papan informasi yang berisikan jadwal kegiatan fisik yang sedang dilaksanakan.

Keterbukaan informasi ini merupakan usaha pemerintah desa untuk melaksanakan prinsip transparansi dalam pengelolaan Alokasi dana desa. Dari sisi prinsip akuntabilitas pelaksanaan alokasi dana desa ditempuh melalui sistem pelaporan yaitu pelaporan bulanan dan laporan masing-masing tahapan kegiatan.

Di dalam pelaksanaan alokasi dana desa senantiasa dilaporkan perkembangan pelaksanaan kegiatan oleh pengelola Alokasi dana desa di tingkat desa, terutama tentang

${ }^{8}$ Muh. Yusuf, Kepala Desa Benteng Paremba, Wawancara, Pinrang 30 Desember 2017.

${ }^{9}$ Burhanuddin, Sekretaris Desa Benteng Paremba, Wawancara, Pinrang 23 Desember 2017. 
kegiatan fisik dan penyerapan dana. Dengan demikian dapat diketahui bahwa tanggung jawab pengelola Alokasi dana desa di tingkat desa sudah memenuhi ketentuan pembuatan laporan kegiatan Alokasi dana desa yang bertahap dan laporan akhir kegiatan.

Penanggungjawaban pelaksanaan program Alokasi dana desa kepada pemerintah tingkat atasnya dilakukan melalui sistem pelaporan yang dilakukan secara periodik. Laporan pelaaksanaan Alokasi dana desa terdiri dari laporan pendahuluan, laporan masing-masing tahap kegiatan, laporan bulanan dan laporan akhir kegiatan yang disusun secara komperehensip

c. Pertanggung jawaban Alokasi Dana Desa

Pertanggung jawaban Alokasi Dana desa di desa benteng paremba terintegrasi dengan pertanggung jawaban APBDes. Hal ini Sesuai dengan peraturan dalam negeri nomor 37 tahun tahun 2007 tentang keuangan desa. Peraturan tersebut dimaksudkan untuk memberikan landasan hukum bidang keuangan desa, sumber keuangan desa, dan anggaran pendapatan dan belanja desa. ${ }^{10}$

Penguatan keuangan desa dilakukan untuk menguatkan pilar transparansi dan akuntabilitas. Pengelolaan keuangan desa harus harus dilakukan secara efisien, efektif transparansi dan akuntabel. Alokasi dana desa yang merupakan salah satu sumber utama pendapatan desa juga harus dipertanggungjawabkan secara transparan kepada masyarakat maupun kepada pemerintah kabupaten sebagai instuisi pemberi kewenangan. Selain itu pertanggungjawaban kepada masyarakat dilakukan secara periodik setiap tiga bulan sekali melalui forum evaluasi pelaksanaan Alokasi Dana desa yang dipimpin oleh kepala desa. Berikut hasil wawancara dengan kepala desa benteng paremba

"setiap tiga bulan sekali selalu diadakan evaluasi pelaksanaan Alokasi dana desa yang mengundang tokoh masyarakat, LPM, BPD. Evaluasi ini dilakukan untuk mewujudkan transparansi dalam Alokasi dana desa dan diharapkan adanya masukan- masukan demi berjalannya Alokasi dana desa". ${ }^{11}$

Penyampaian laporan dilaksanakan melalui jalur struktural yaitu dari tim pelaksana tingkat desa dan diketahui kepala desa ke tim pendamping tingkat kecamatan secara bertahap. Sedangkan untuk pengelolaan administrasi keuangan yang dilaksanakan di desa Benteng Paremba dapat dikatakan sesuai dengan prinsip akuntabiliatas sebagaimana hasil wawancara dengan bendahara desa tersebut sebagai berikut:

"kepala desa dan bendahara desa mengambil dana desa dari bank kemudian diberikan kepada bendahara tim pelaksana Alokasi dana desa. Dari bendahara tim pelaksana Alokasi dana desa yang sifatnya untuk alokasi pemerintah desa dikembalikan lagi ke bendahara desa". ${ }^{2}$

Pemahaman tentang pengelolaan administrasi keuangan Alokasi dana desa dapat diketahui pula dari hasil wawancara berikut:

" melalui di BKUkan, buku kas pembantu umum, dilengkapi dengan bukti- bukti pendukung yang sah dan dapat dipertanggung jawabkan. Yang penerima jika berbentuk bantuan sosial, juga dimintakan surat penerimaan dan nota-nota yang sah". ${ }^{13}$

10 Peraturan Menteri Dalam Negeri Nomor 37 tahun 2007 Tentang Pedoman Pengelolaan Keuangan Desa, Dalam Pasal 15.

${ }^{11}$ Muh. Yusuf, Kepala Desa Benteng Paremba, Wawancara, Pinrang 30 Desember 2017.

12 Burhanuddin, Sekretaris Desa Benteng Paremba, Wawancara, Pinrang 30 Desember 2017.

${ }^{13}$ Ahmad, Bendahara Desa Benteng Paremba, Wawancara, Pinrang 30 Desember 2017. 
Informasi tersebut menunjukkan bahwa sistem pertanggungjawaban pelaksanaan Alokasi dana desa di desa benteng paremba telah melaksanakan prinsip akuntabilitas. Dan pengelolaan Alokasi dana desa juga telah melaksanakan pertanggungjawaban administrasi keuangan Alokasi dana desa dengan baik yaitu setiap pembelanjaan yang bersumber dari Alokasi dana desa harus disertai dengan bukti.

Evaluasi pelaksanaan program Alokasi dana desa tersebut juga membimbing mansyarakat untuk berpartisipasi aktif dalam memberikan masukan dan koreksi dengan adanya kerja sama saling membantu antar perangkat desa, bendahara, tim pelaksana alokasi dana desa agar pelaporan alokasi dana desa dapat diselesaikan dengan cepat dan tepat. Dapat diketahui bahwa pelaksana alokasi dana desa sudah memahami dan mengerti tentang tata kelola administrasi keuangan alokasi dana desa karena selalu ada petunjuk dari pemerintah kabupaten.

Hal ini didukung penerapan di lapangan yang menunjukkan bahwa semua uang yang telah dikeluarkan sudah dipertanggungjawabkan secara fisik dan juga secara administrasi keuangan. Hasil pembangunan yang bersumber dari alokasi dana desa di desa Benteng Paremba Kecamatan Lembang Kabupaten Pinrang dapat dilihat dari tabel berikut:

Tabel 1

Hasil sarana prasarana yang dibangun dengan ADD tahun 2017

\begin{tabular}{|c|c|c|}
\hline No & Sarana yang dibangun & Hasil \\
\hline 1. & Pengembangan pipanisasi air bersih & Baik \\
\hline 2. & Pembangunan wc 3 unit & Baik \\
\hline 3. & Pembangunan jalan beton (60 meter) & Baik \\
\hline 4. & Pembangunan jembatan beton (7 X9 meter) & Baik \\
\hline 5. & Pengadaan lampu jalan & Baik \\
\hline
\end{tabular}

Dari data tersebut menunjukkan bahwa hasil yang dicapai di desa benteng paremba baik secara fisik dapat dipertanggungjawabkan. Sedangkan secara administrasi perlu adanya pebaikan dan pembenahan untuk kesempurnaan penerapan prinsip akuntabilitas. Dengan dilakukannya prinsip akuntabilitas secara bertahap akhirnya akan mendukung kepercayaan masyarakat terhadap pelaksanaan pembangunan desa yang pada akhirnya akan tercapai tingkat partisipasi masyarakat desa yang secara komulatif akan mendukung keberhasilan pembangunan daerah.

Evaluasi pelaksanaan program alokasi dana desa juga membimbing masyarakat untuk berpartisipasi aktif dalam memberikan masukan dan koreksi pelaksanaan alokasi dana desa. Dalam hal ini pemerintah desa juga harus merespon kritik dan saran masyarakat dalam forum musyawarah desa yang diharapkanprogram alokasi dana desa kedepannya bisa lebih baik lagi. Prinsip paryisipasi pun terwujud dengan pelaksanaan alokasi dana desa dengan mengikutsertakan masyarakat. Selain itu, forum evaluasi yang dilaksanakan tersebut juga telah menerapkan prinsip transparansi dalam pertanggungjawaban alokasi dana desa secara priodik.

\section{Pandangan Hukum Islam Terhadap Pengelolaan Alokasi Dana Desa di Desa benteng Paremba}

Iqtishaduna: Jurnal Ilmiah Mahasiswa Jurusan Hukum Ekonomi Syariah 
Islam mengajarkan tentang studi perencanaan secara jelas terperinci dalam alqur'an dan as-sunnah sebagai sumber segala ilmu yang menjadi pedoman untuk menindaklanjuti berbagai macam permasalahan hidup. Begitupun dengan akuntabilitas dan transparansi sebagai bentuk pengelolaan alokasi dana desa di desa benteng paremba.

Transparansi anggaran adalah salah satu bentuk Tabligh. Tabligh atau menyampaikan segala sesuatu tanpa ada yang disembunyikan mengandung makna kejujuran dalam berbicara, kejujuran dalam niat dan kemauan, kejujuran dalam perencanaan, kejujuran dalam melaksanakan rencana, kejujuran dalam tindakan, kejujuran dalam merealisasikan dalm semua ketentuan agama. Dalam pengelolaan anggaran kejujuran ini tidak bisa dijalankan kecuali dengan transparansi anggaran. Maka menjalankan transparansi anggaran adalah wajib. Ini berarti dalam pandangan hukum islam, menghindari transparansi anggaran adalah kemaksiatan yang dapat menghapus semua pahala ibadah kepada tuhan.

Dengan demikian transparansi menjadi instrumen penting yang dapat menyelamatkan uang rakyat dari perbuatan korupsi. Dengan adanya transparansi hendaknya para pemegang kekuasaan mencerminkan sikap keterbukaan sesuai dengan firman allah dalam surah an-nahl ayat 101 sebagai berikut:

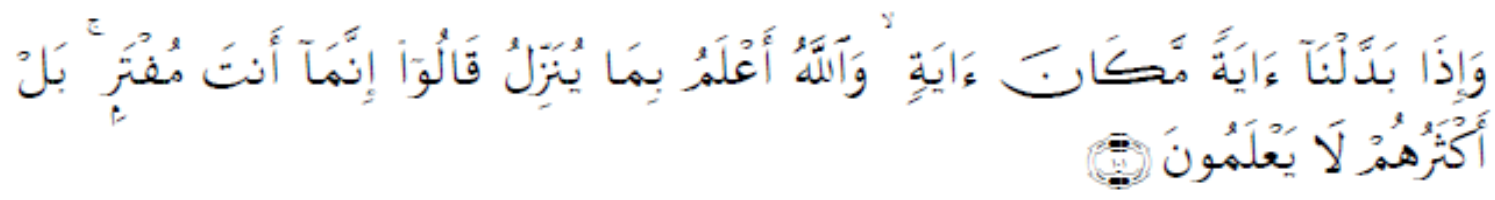

Terjemahannya:

"Dan apabila Kami letakkan suatu ayat di tempat ayat yang lain sebagai penggantinya Padahal Allah lebih mengetahui apa yang diturunkan-Nya, mereka berkata: "Sesungguhnya kamu adalah orang yang mengada-adakan saja". Bahkan kebanyakan mereka tiada mengetahui."

Ayat ini meenguraikan bahwa dan apabila kami mengganti suatu ayat alqur'an di tempat ayat yang lain padahal Allah yang pengetahuannya maha luas lebih mengetahui dari siapapun apa yang diturunkannya, antaralain menyangkut kapan dan apa yang digantidan menggantikan serta apa yang merupakan kemaslahatan masyarakat. apabila terjadi yang demikian, sebagian mereka yang tidak mengetahui itu berkata: "sesungguhnya engkau, wahai nabi Muhammad, berbohong dalam pengakuanmu bahwa penggantian itu bersumber dari allah, bahkan engkau banyak sekali berbohong sehingga engkau sebenarnya adalah pengada-ada, yakni pembohong.",14

Akuntabilitas dan transparansi merupakan bentuk pengelolaan dana desa di desa benteng paremba dimana Akuntabilitas dalam perspektif hukum islam yang menggambarkan suatu pertanggung jawaban yang mutlak. Sebagai salah satu contoh sifat nabi yakni amanah dalam menjalankan tugas atau wewenang. Mengenai bentuk akuntabilitas tersebut dapat kita lihat dalam firman allah surat al-ahzab ayat 72-73

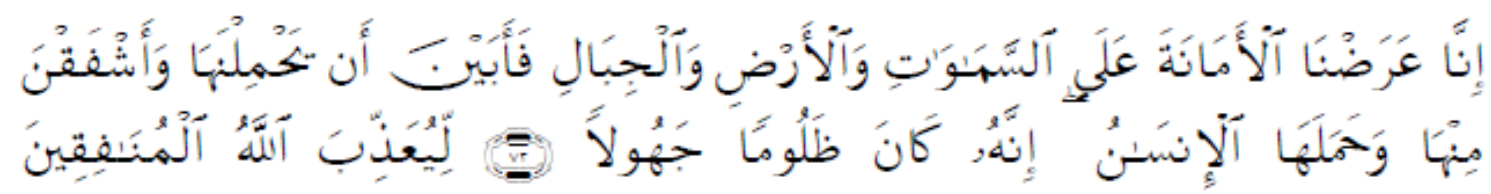

${ }^{14}$ Quraish Shihab, Tafsir Al-Misbah, (Jakarta: Lentera Hati, 2002), h. 730. 


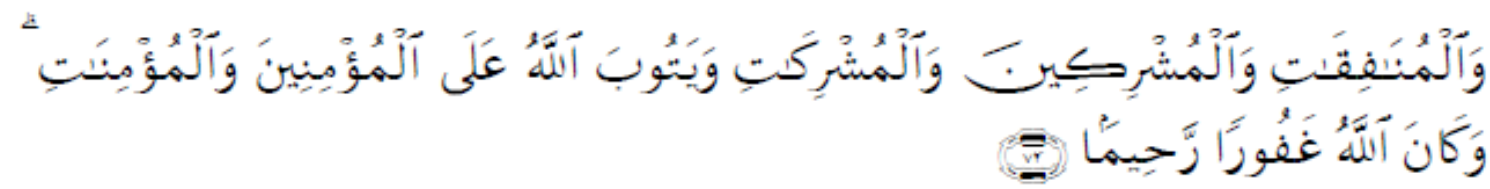

Terjemahnya:

"Sesungguhnya Kami telah mengemukakan amanat kepada langit, bumi dan gunung-gunung, Maka semuanya enggan untuk memikul amanat itu dan mereka khawatir akan mengkhianatinya, dan dipikullah amanat itu oleh manusia. Sesungguhnya manusia itu Amat zalim dan Amat bodoh. Sehingga Allah mengazab orang-orang munafik laki-laki dan perempuan dan orang-orang musyrikin laki-laki dan perempuan; dan sehingga Allah menerima taubat orang- orang mukmin laki-laki dan perempuan. dan adalah Allah Maha Pengampun lagi Maha Penyayang."

Al-'Aufi berkata dari Ibnu Abbas : "yang dimaksud dengan al-Amanah adalah ketaatan yang ditawarkan kepada mereka sebelum ditawarkan kepada adam akan tetapi mereka tidak menyanggupinya. Lalu allah berfirman kepada adam : "aku memberikan amanah kepada langit dan bumi serta gunung-gunung, akan tetapi mereka tidak menyanggupinya. Apakah engkau sanggup untuk menerimanya?" dia menjawab: "ya rabb-ku, apa isi nya?" allah berfirman: " jika engkau berbuat baik, engkau akan diberi balasan. Dan jika engkau berbuat buruk, engkau akan disiksa." Lalu adam menerimanya dan menyanggupinya. Itulah firman allah "dan pikullah amanat itu oleh manusia, sesungguhnya manusia itu amat zhalim dan amat bodoh.", 15

Firman allah: "sehingga allah mengadzab orang-orang munafik laki-laki dan perempuan dan orang-orang musyrikin laki-laki dan perempuan." Yaitu nak adam bersedia menanggung amanah ini, yakni beruoa taklif, sehingga allah mengadzab orangorang munafik laki-laki dan perempuan diantara mereka. Mereka itu adalah orang-orang yang menampakkannkeimanan, karena takut terhadap lingkungannya serta menyembunyikan kekafiran karena mengikuti lingkungannya. ${ }^{16}$ "dan orang-orang musyrikin laki-laki dan perempuan." mereka adalah orang- orang yang zhahir dan batinnya musyrik kepada allah dan melanggar rasul-nya. "dan sehingga allah menerima taubat orang-orang mukmin laki-laki dan perempuan." Agar allah menyayangi orangorang mukmin, yaitu orang-orang yang beriman kepada allah, para malaikatnya, kitabkitabnya, dan para rasulnya serta mengajarkan ketaatan. "dan adalah allah maha pengampun lagi maha penyayang." 17

Sebagai pelaksana amanat dari pemerintah pusat dan daerah, pemerintah desa memiliki kewenangan dan hak-hak dalam melaksanakan tugas-tugasnya. Dalam hal ini yang menjadi hak pemerintah desa adalah sebagai ulil amri dimana warga masyarakat memiliki kewajiban menaati ulil amri agar terealisasinya pelaksanaan tugas-tugas yang kewenangan di segala bidang dalam unit lingkup pemerintahan desa. Sebagaimana dalam alqur'an telah dijelaskan tentang kewajiban mentaati ulil amri dalam surah an-nisa ayat 59 sebagai berikut:

\footnotetext{
${ }^{15}$ Abdullah Bin Muhammad Alu Syaikh, Lubaabut Tafsir Min Ibni Katsiir, (Jakarta: Pustaka Imam Asy-Syafi'i, 2010), h. 121.

${ }^{16}$ Abdullah Bin Muhammad Alu Syaikh, Lubaabut Tafsir Min Ibni Katsiir, (Jakarta :Pustaka Imam Asy-Syafi'i, 2010), h. 123.

${ }^{17}$ Abdullah Bin Muhammad Alu Syaikh, Lubaabut Tafsir Min Ibni Katsiir, h. 124 


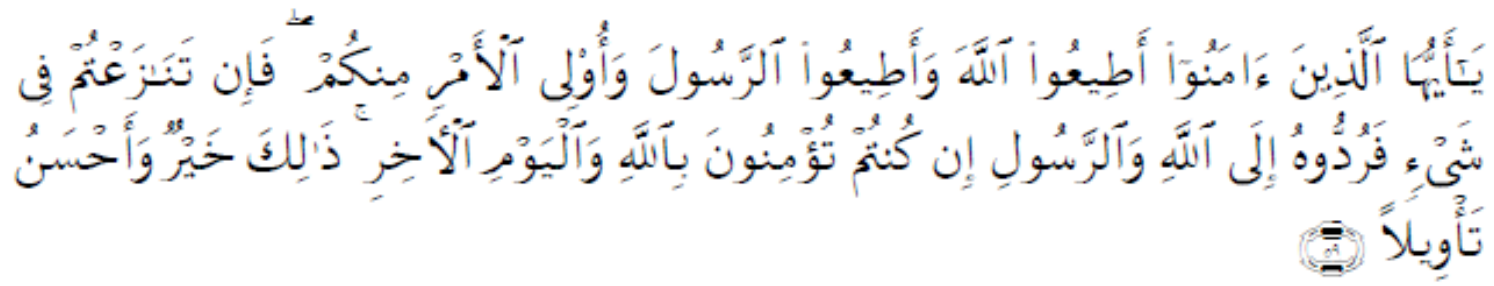

Terjemahannya:

"Hai orang-orang yang beriman, taatilah Allah dan taatilah Rasul (Nya), dan ulil amri di antara kamu. kemudian jika kamu berlainan Pendapat tentang sesuatu, Maka kembalikanlah ia kepada Allah (Al Quran) dan Rasul (sunnahnya), jika kamu benarbenar beriman kepada Allah dan hari kemudian. yang demikian itu lebih utama (bagimu) dan lebih baik akibatnya." 18

Ayat di atas memerintahkan kaum mukminin agar menaati putusan hukum dari siapa pun yang berwewenang menetapkan hukum. Secara berurutan dinyatakan- Nya; Wahai orang-orang yang beriman, taatilah Allah dalam perintah-perintah-Nya yang tercantum dalam al-Qur'an dan taatilah Rasul-Nya, yakni Muhammad saw. dalam segala macam perintahnya, baik perintah melakukan sesuatu, maupun perintah untuk tidak melakukannya, sebagaimana tercantum dalam sunnah nya yang sahih, dan perkenankan juga perintah ulil amri, yakni yang berwewenang menangani urusan-urusan kamu, selama mereka merupakan bagian di antara kamu wahai orang- orang mukmin, dan selama perintahnya tidak bertentangan dengan perintah Allah atau perintah Rasul-Nya. Maka jika kamu tarik-menarik, yakni berbeda pendapat tentang sesuatu karena kamu tidak menemukan secara tegas petunjuk Allah dalam al- Qur'an, dan tidak juga petunjuk Rasul dalam sunnah yang shahih, maka kembalikanlah ia kepada nilai-nilai dan jiwa tuntunan Rasul saw. yang kamu temukan dalam sunnahnya, jika kamu benar-benar beriman secara mantap dan besinambung kepada Allah dan hari Kemudian. Yang demikian itu, yakni sumber hukum ini adalah baik lagi sempurna, sedang selainnya buruk-atau memiliki kekurangan, dan di samping itu, ia juga lebih baik akhiratnya, baik untuk kehidupan dunia kamu maupun kehidupan akhirat kelak. ${ }^{19}$

Pengelolaan dana desa di desaBenteng Paremba sudah sesuai dengan hukum Islam, dimana di desa Benteng Paremba telah menerapkan sistem transparansi dan akuntabilitas dalam mengelola keuangan desa sebagaimana dalam islam disebut Tabgligh dan Amanah. Dan selama proses pengelolaan tidak ditemukan adanya penyelewengan dana.

\section{KESIMPULAN}

Berdasarkan pembahasan diatas, penulis mengambil kesimpulan:

1. Bentuk pengelolaan alokasi dana desa di desa benteng paremba Kabupaten Pinrang yaitu Melalui tahapan perencanaan pengelolaan alokasi dana desa dimulai dari musyawarah dusun terlebih dahulu untuk menampung aspirasi masyarakat dan menetapkan usulan yang termasuk prioritas masing-masing dusun. Tahapan pelaksanaan pengelolaan alokasi dana desa dilakukan oleh tim pelaksana kegiatan desa. Pertanggungjawaban pengelolaan alokasi dana desa dilakukan dengan menyampaikan pelaporan yang dilaksanakan melalui jalur struktural yaitu dari tim

\footnotetext{
${ }^{18}$ Kementrian Agama Republik Indonesia, Syamil Al-Quran, (Bandung: Sygma, 2012), h. 87.

${ }^{19}$ M. Quraish Shihab, Tafsir Al-Mishbah Pesan, Kesan dan Keserasian Al-Qur'an, (Jakarta: Lentera Hati, Volume 3, 2002) h. 482-486.
} 
pelaksana tingkat desa melaporkan pertanggungjawaban ke bendahara desa yang kemudian dilaporkan kembali oleh kepala desa kepada kecamatan.

2. Pandangan Hukum Islam Terhadap Pengelolaan Alokasi Dana Desa di Desa Benteng Paremba yaitu dimana dalam Islam diajarkan untuk selalu menanamkan sifat keterbukaan dan kejujuran dalam menjalan suatu perencanaan dalam hidup baik dalam bentuk individu maupun bermasyarakat. Sama halnya dalam pengelolaan alokasi dana desa kita senantiasa menerapkan sistem transparansi/Tabligh dan akuntabilitas/amanah karena hukumnya adalah wajib dan jika melanggar berarti kita telah melakukan kemaksiatan yang akan menghapus segala amal ibadah kepada allah. Sebagaimana tertuang dalam alqur'an surah an-nahl ayat 101 mengenai transparansi dan surah al-ahzab ayat 72-73. 


\section{DAFTAR PUSTAKA}

Iqbal Muhammad. Fiqh Siyasah, Kotekstualisasi Doktrin Politik Islam. Jakarta: Prenadamedia Group, 2014.

Kementrian Agama Republik Indonesia, Syamil Al-Quran, Bandung: Sygma, 2012

Kementerian Dalam Negeri. Pedoman Pengelolaan Keuangan Desa. Jakarta: Menteri Dalam Negeri, 2007.

Lestari Sri. Analisis Akuntabilitas Pengelolaan Alokasi Dana Desa. Surakarta: Institut Agama Islam Negeri Surakarta, 2017.

Peraturan Menteri Dalam Negeri Nomor 37 Tahun 2007 tentang Pedoman Pengelolaan Keuangan Desa.

Peraturan Pemerintah RI Nomor 22 Tahun 2015 Tentang Perubahan Atas Peraturan Pemerintah Nomor 60 Tahun 2014 Tentang Dana Desa yang Bersumber dari Anggaran Pendapatan dan Belanja Negara.

Saleh Dahlan, Qamaruddin. Azbabun Nuzul Latar Belakang Turunnya Ayat-ayat AlQur'an. Bandung: CV. Diponegoro, 1997.

Shihab M. Quraish, Tafsir Al-Mishbah Pesan, Kesan dan Keserasian Al-Qur'an. Jakarta: Lentera Hati, Volume 3, 2002.

Soekanto, Soejono. Metode Penelitian Hukum. Jakarta: UII Pres, 1984.

Suggono, Bambang. Metodologi Penelitian Hukum. Jakarta: Raja Grafindo Persada, 2007.

Sugiyono, Metode Penelitian Kuantitatif Kualitatif dan R\&D. Bandung: Alfabeta, 2008.

Sumaryadi, I Nyoman, Perencanaan Pembangunan Daerah Otonom dan Pemberdayaan Masyarakat. Jakarta: Citra Utama, 2005.

Suryaningrat, Bayu. Pemerintahan dan Administrasi Desa, Jatinagor: Alqaprint, 1976.

Syaikh, Abdullah bin Muhammad bin Abdurrahman bin Ishaq. Tafsir Ibn Katsir. Jakarta: Pustaka Imam Syafi'i, 2010.

Syarifuddin, Amir. Pembaharuan Dalam Pemikiran Hukum Islam. Cet. II; Padang: Angkasa Raya, 1993.

Tim Visi Yustisia, Pedoman Resmi Petunjuk Pelaksana Dana Desa. Jakarta: Visimedia, 2016.

, Undang Undang Nomor 6 Tahun 2014 Tentang Desa dan Peraturan Terkait. Jakarta: Visimedia, 2015.

Trisantono, Bambang. Pedoman Penyelenggaraan Pemerintahan Desa. Bandung: Fokusmedia, 2011.

Undang-Undang RI Nomor 6 tahun 2014 Tentang Desa.

Universitas Islam Negeri Alauddin Makassar, Pedoman Penulisan Karya Tulis Ilmiah, Makalah, Skripsi, Tesis, Disertasi dan Laporan Penelitian. Cet. I; Makassar: Alauddin University Press, 2013.

Widjaja, Otonomi Daerah dan Daerah Otonom. Jakarta: PT. Rajagrafindo Persada, 2007. 